\title{
United Kingdom Patent Decisions 2019
}

\author{
Robyn Trigg
}

Published online: 14 February 2020

(C) The Author(s) 2020

\begin{abstract}
This report highlights the main UK patent decisions from 2019, including: two Supreme Court decisions, one concerning obviousness and another concerning employee invention compensation; Court of Appeal decisions relating to FRAND, insufficiency, and SPCs; and several High Court decisions relating to the application of the doctrine of equivalents to numerical values, plausibility of second medical use claims, SPCs, public disclosures, and Arrow declarations.
\end{abstract}

Keywords Arrow declarations - Doctrine of equivalents · Employee compensation · FRAND · Insufficiency · Numerical ranges · Obviousness · Plausibility · Public disclosures · SPCs

Cases Actavis Group PTC EHF v. ICOS Corporation [2019] UKSC 15, [2019] Bus. L.R. 1318; Actavis Group PTC EHF v. ICOS Corporation [2017] EWCA Civ 1671, [2017] 11 WLUK 8; Actavis Group PTC EHF v. ICOS Corporation [2016] EWHC 1955 (Pat), [2016] 8 WLUK 146; Actavis UK Ltd v. Eli Lilly \& Co [2017] UKSC 48, [2018] 1 All E.R. 171; Anan Kasei Co Ltd v. Neo Chemicals and Oxides Ltd (formerly Molycorp Chemicals and Oxides Limited) [2019] EWCA Civ 1646, [2019] 10 WLUK 168; Anan Kasei Co Ltd v. Molycorp Chemicals \& Oxides (Europe) Ltd [2018] EWHC 843 (Pat), [2018] 4 WLUK 371; Arrow Generics Ltd v. Merck \& Co Inc [2007] EWHC 1900 (Pat), [2008] Bus. L.R. 487; Biogen Inc v. Medeva Plc [1996] UKHL 18, [1996] 10 WLUK 486; Case C-121/17 Teva UK and Others v. Gilead Sciences Inc [2018]; Huawei Technologies Co Ltd v. Conversant Wireless Licensing SARL [2019] EWCA Civ 38, [2019] 1 WLUK 278; Conversant Wireless Licensing SARL v. Huawei Technologies Co Ltd [2018] EWHC 808 (Pat),

Robyn Trigg is a non-practising solicitor.

R. Trigg $(\bowtie)$

DPhil Candidate, Magdalen College, University of Oxford, Oxford, UK

e-mail: robyn.trigg@magd.ox.ac.uk 
[2018] 4 WLUK 187; Eli Lilly and Co v. Genentech Inc [2019] EWHC 387 (Pat), [2019] 3 WLUK 15; Eli Lilly and Co v. Genentech Inc [2019] EWHC 388 (Pat), [2019] 3 WLUK 4; E Mishan and Sons Inc (t/a Emson) v. Hozelock Ltd [2019] EWHC 991 (Pat), [2019] 4 WLUK 336; Ferrexpo AG v. Gilson Investments Ltd [2012] EWHC 721 (Comm); [2012] 4 WLUK 41; FujiFilm Kyowa Kirin Biologics Co Ltd v. AbbVie Biotechnology Ltd [2017] EWHC 395 (Pat), [2017] 3 WLUK 104; Gillette Safety Razor v. Anglo-American Trading [1913] 30 RPC 465; Glaxo Group Ltd v. Vectura Ltd [2018] EWCA Civ 1496, [2019] Bus. L.R. 648; Icescape Ltd v. Ice-World International BV [2018] EWCA Civ 2219, [2018] 10 WLUK 187; Jushi Group Co Ltd v. OCV Intellectual Capital LLC [2018] EWCA Civ 1416, [2018] 6 WLUK 344; Kirin-Amgen Inc v. Hoechst Marion Roussel Limited [2004] UKHL 46, [2005] 1 All E.R. 667; Owusu v. Jackson [2005] QB 801; Pfizer Ltd v. F HoffmannLa Roche AG [2019] EWHC 1520 (Pat), [2019] 6 WLUK 324; Regen Lab SA $v$. Estar Medical Ltd [2019] EWHC 63 (Pat), [2019] 1 WLUK 135; Shanks v. Unilever Plc [2019] UKSC 45, [2019] 1 W.L.R. 5997; Société Technique de Pulverisation Step v. Emson Europe Ltd [1993] RPC 513; Takeda UK Ltd v. F Hoffman-La Roche AG [2019] EWHC 1911, [2019] Bus. L.R. 2681; Teva UK Ltd v. Gilead Sciences Inc [2019] EWCA Civ 2272, [2019] 12 WLUK 276; Teva UK Ltd v. Gilead Sciences Inc [2018] EWHC 2416 (Pat), [2018] 9 WLUK 185; Teva UK Ltd v. Gilead Sciences Inc [2017] EWHC 13 (Pat), [2017] 1 WLUK 130; Unwired Planet International Ltd v. Huawei Technologies Co Ltd [2018] EWCA Civ 2344, [2018] 10 WLUK 355; Warner-Lambert Co LLC v. Generics (UK) Ltd (t/a Mylan) [2018] UKSC 56, [2019] 3 All E.R. 95; Windsurfing International Inc v. Tabur Marine (Great Britain) Ltd [1985] RPC 59.

Legislation Civil Procedure Rules; Patents Act 1977; Regulation 469/2009 concerning the supplementary protection certificate for medicinal products; Regulation 1215/2012 on jurisdiction and the recognition and enforcement of judgments in civil and commercial matters (recast).

\section{Huawei Technologies Co Ltd v. Conversant Wireless Licensing SARL}

The year started with a Court of Appeal decision in Huawei Technologies Co Ltd $v$. Conversant Wireless Licensing SARL ${ }^{1}$ concerning the ongoing issue of FRAND and whether the English courts have jurisdiction to grant global FRAND licences.

This case concerned an appeal brought by Huawei and ZTE (the appellants) against the first instance decision of Carr J, Conversant Wireless Licensing SARL $v$. Huawei Technologies Co Ltd, ${ }^{2}$ where Carr J rejected the appellants' challenge to the English courts' jurisdiction to determine a global FRAND licence when the relevant UK sales amounted $1 \%$ or less of worldwide sales on which Conversant claimed royalties. The Court of Appeal, with Floyd LJ setting out the reasoning and Patten LJ and Flaux LJ agreeing, dismissed the appellants' appeal.

\footnotetext{
${ }^{1}$ [2019] EWCA Civ 38, [2019] 1 WLUK 278.

2 [2018] EWHC 808 (Pat), [2018] 4 WLUK 187. See previous summary in R. Trigg, "United Kingdom Patent Decisions 2018”. IIC 50:331-351 (2019). https://doi.org/10.1007/s40319-019-00796-y.
} 
In the first instance decision, Conversant had brought claims against Huawei and ZTE (an English and a Chinese company in each of the Huawei and ZTE groups) for alleged infringement of patents it claims to be standard essential patents (SEPs). Huawei and ZTE challenged the jurisdiction of the English courts to hear Conversant's claims on the basis of two main arguments: (i) justiciability - the English court has no jurisdiction to decide the claims as they are, in substance, claims for infringement of foreign patents, the validity of which is in dispute; and, in the alternative (ii) forum non conveniens - if the English courts do have jurisdiction to hear the claims, then they should decline it because England is not the most appropriate forum to hear the claim, rather, China is.

In light of the Court of Appeal's previous decision in Unwired Planet International Ltd v. Huawei Technologies Co Ltd, ${ }^{3}$ the appellants accepted that their justiciability argument was no longer arguable before the Court of Appeal. Thus, this decision concerned only the second argument advanced by the appellants, forum non conveniens.

The Court of Appeal first dealt with the position in relation to the appellants' UK domiciled companies. As a result of them being domiciled in the UK, the Court held that Art. 4 of the Brussels I Recast Regulation ${ }^{4}$ was applicable. ${ }^{5}$ Article 4(1) states “... persons domiciled in a Member State shall, whatever their nationality, be sued in the courts of that Member State". The Court of Appeal also cited the CJEU decision of Owusu v. Jackson ${ }^{6}$ which decided that an English court could not apply the doctrine of forum non conveniens to decline jurisdiction over a claim against a person domiciled in a contracting state on the ground that the natural forum for the claims was the courts of a non-contracting state. ${ }^{7}$

However, Art. 24 of the Brussels I Recast Regulation states that the courts of a Member State shall have exclusive jurisdiction, regardless of domicile of the parties involved, in proceedings concerning the registration and validity of patents. The issue before the Court of Appeal here, which was not decided in Owusu v. Jackson, ${ }^{8}$ was whether the conclusion reached in Owusu v. Jackson ${ }^{9}$ in relation to the availability of the plea of forum non conveniens applied in cases where Art. 24 applies, i.e. cases concerning the registration and validity of patents. Floyd LJ concluded, citing Smith $\mathrm{J}$ in Ferrexpo AG v. Gilson Investments Ltd, ${ }^{10}$ that the court has discretion as to whether to assume jurisdiction under Art. 4 of the Brussels I Recast Regulation for proceedings concerning subject matter covered by Art. $24 .^{11}$

\footnotetext{
3 [2018] EWCA Civ 2344, [2018] 10 WLUK 355. See previous summary in R. Trigg, "United Kingdom Patent Decisions 2018”. IIC 50:331-351 (2019). https://doi.org/10.1007/s40319-019-00796-y.

${ }^{4}$ Regulation 1215/2012 on jurisdiction and the recognition and enforcement of judgments in civil and commercial matters (recast).

5 Supra note 1, para. [25].

${ }^{6}$ [2005] QB 801.

7 Supra note 1, para. [26].

8 Supra note 6.

9 Ibid.

${ }^{10}$ [2012] EWHC 721 (Comm); [2012] 4 WLUK 41.

11 Supra note 1, para. [29].
} 
The Court of Appeal then dealt with the position with respect to the appellants' Chinese companies. At [30] Floyd LJ stated that there are three hurdles which a party must overcome in order to obtain permission to serve proceedings out of the jurisdiction: (1) the claim comes within one of the gateways within CPR 6 PDB; (2) there must be a serious issue to be tried; and (3) England and Wales must be the proper place to bring the claim. In this case, it is the conclusion reached at first instance by Carr $\mathrm{J}$ with respect to the third hurdle that was appealed. The appellants submitted, and the Court of Appeal accepted that, when considering this third hurdle, the totality of the dispute must be considered and not just the arguments presented by the claimant and the case must not be characterised in a way which risks pre-judging the analysis of where the proper forum is. ${ }^{12}$

On the evidence before him at first instance, Carr $\mathrm{J}$ had concluded that the Chinese courts did not have jurisdiction to decide upon the essentiality or infringement of non-Chinese patents. He also concluded that the Chinese courts could not determine FRAND rates without the agreement of both parties concerned. Conversant had not agreed to the Chinese courts making such a determination and Carr $\mathbf{J}$ concluded that this refusal was reasonable. So, on the basis of this reasoning, Carr $\mathbf{J}$ had concluded that China was not an available alternative forum.

In this appeal, the appellants both sought to adduce further evidence of Chinese law before the Court of Appeal. ${ }^{13}$ The appellants sought to introduce Guidelines issued by the Guangdong High People's Court regarding the adjudication of disputes concerning SEPs. These Guidelines had been issued 10 days after Carr J handed down his first instance judgment, but before the resulting Order was sealed. Paragraph 16 of these Guidelines states that where the territorial scope of the SEPs in question exceeds the territorial scope of the court and the other party does not explicitly object (or the objection is deemed unreasonable), then the court can determine the royalty.

The appellants sought to rely on this as further evidence to illustrate that the Chinese courts would exercise jurisdiction to determine essentiality, infringement and FRAND rates for a global portfolio where both parties had consented or refusal of consent was deemed unreasonable. The appellants provided expert evidence which concluded that in circumstances such as those in this case, the Chinese courts would deem Conversant's refusal to agree to the Chinese courts determining the royalty rates to be unreasonable. Conversant submitted expert evidence that disagreed with this conclusion and highlighted the fact that there is no case law setting out the circumstances where the Chinese courts would conclude that a party's objection is unreasonable.

The Court of Appeal agreed with Conversant's expert evidence and concluded that it was speculative to try to suggest how the Chinese courts would interpret these Guidelines. ${ }^{14}$ Floyd LJ therefore concluded that whilst this further evidence would be admissible under the first part of the relevant test (i.e. it could not have been adduced at the first instance proceedings), it did not pass the threshold for the second part of the test (i.e. it would not have had an influence on the outcome of the first instance proceedings).

\footnotetext{
12 Supra note 1, paras. [32]-[35].

13 Supra note 1, para. [43] et seq.

14 Supra note 1, para. [123].
} 
In concluding how to characterise the dispute for the third hurdle with respect to service on the appellants' Chinese companies, Floyd LJ stated that it was not appropriate to characterise the claim as one for the enforcement of a global portfolio right because such a right does not exist. Floyd $\mathrm{LJ}_{\text {concluded }}{ }^{15}$ that the type of claim Conversant is seeking to bring was dealt with previously by the Court of Appeal in Unwired Planet International Ltd v. Huawei Technologies Co Ltd. ${ }^{16}$ Thus, it could be concluded that Conversant's claims concern a dispute involving the determination of essentiality, infringement and validity of UK patents and the question of FRAND relates to whether Conversant is entitled to relief for infringement of its UK SEPs. ${ }^{17}$

It should be noted that this decision was appealed to the UK Supreme Court and the hearing occurred in October 2019. The decision has not yet been released and therefore we wait to see how matters will proceed in this dispute.

\section{Regen Lab SA v. Estar Medical Ltd}

Next, the High Court dealt with the application of the doctrine of equivalents test, as set out by the Supreme Court in Actavis UK Ltd v. Eli Lilly \& Co, ${ }^{18}$ to a numerical value for the first time in Regen Lab SA v. Estar Medical Ltd. ${ }^{19}$

The case concerned the validity and alleged infringement of Regen's patent for a method of producing platelet rich plasma (PRP) by the defendants. Regen claimed that the defendants were infringing its patent by selling kits in the UK which are subsequently used to prepare PRP according to the method set out in its patent. The defendants launched a counterclaim seeking to revoke Regen's patent on the basis of lack of novelty, lack of inventive step and insufficiency.

With respect to the validity of Regen's patent, the case primarily turned on whether the claims were novel in light of Regen's own disclosures prior to the priority date of the patent. Issues arose between the parties as to the nature of the disclosure made by Regen and whether this disclosure had been made under an obligation of confidence or publicly. Hacon HHJ concluded that a public disclosure of the claimed process had taken place and therefore the claimed processed lacked novelty. ${ }^{20}$ Hacon HHJ did say that he was not shown evidence that the contents of the glass tube used in a prior demonstration that amounted to the public disclosure of the claimed method were disclosed but that this did not matter for the analysis. He concluded that there was evidence that the tube used was a Regen tube and that those tubes were for sale before the priority date; this, therefore, enabled the disclosure. ${ }^{21}$ Hacon HHJ also determined that Regen's patent lacked inventive step. ${ }^{22}$

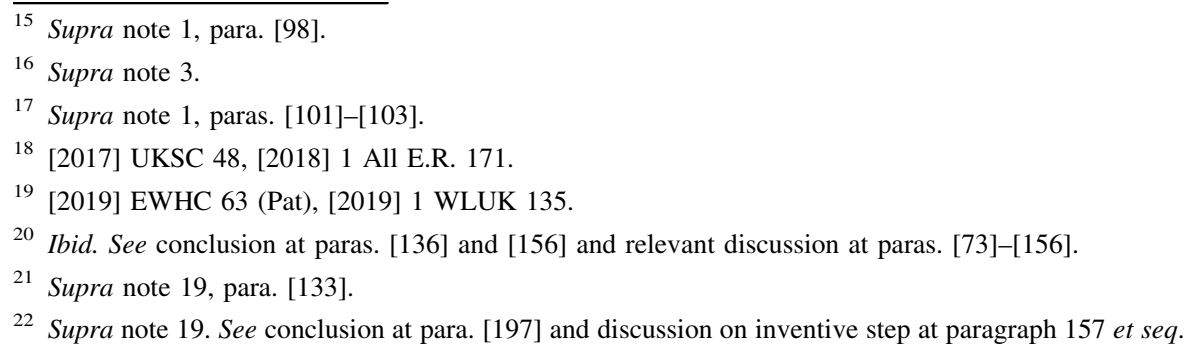


With respect to infringement, this turned on whether the use of a separator tube with sodium citrate at a different molarity to that specified in the claims infringed the patent by virtue of the doctrine of equivalents. Hacon HHJ considered the issue of infringement by applying the principles of claim interpretation set out in Actavis $^{23}$ and as reviewed by the Court of Appeal in Icescape Ltd v. Ice-World International $B V^{24}$

First, Hacon HHJ considered whether multiple differences or variants between the alleged infringement and claim on a normal construction should be assessed separately or taken together. Hacon HHJ concluded that the key question should be whether the alleged infringing product or process is a variant falling within the scope of the claim when taking all equivalents into account. ${ }^{25}$

Then Hacon HHJ turned to consider how the Actavis ${ }^{26}$ doctrine of equivalents should be applied to claims with numerical limitations. Hacon HHJ noted that the law relating to claims with numerical content was recently revisited by the Court of Appeal in Jushi Group Co Ltd v. OCV Intellectual Capital LLC ${ }^{27}$ and it was concluded that the approach to dealing with claims with numerical content was no different than any other claims. ${ }^{28}$ Hacon HHJ concluded that he does not think this has been changed by Actavis and therefore the questions set out in Actavis should be applied in the same way. ${ }^{29}$

Hacon HHJ considered the law before Actavis ${ }^{30}$ and concurred with obiter dicta from Hoffmann LJ (as he then was) in Société Technique de Pulverisation Step $v$. Emson Europe $\operatorname{Ltd}^{31}$ that said that purposive construction did not mean that an integer in a claim can be struck out if it does not appear to make a difference to the inventive concept. ${ }^{32}$ However, Hacon HHJ stated that, as confirmed by the Court of Appeal in Icescape ${ }^{33}$ the focus of construction should no longer be on the claim language itself (the "invention as a whole"), but should concern the "inventive concept". 34 Hacon HHJ distinguished between the invention as a whole and the inventive concept by concluding that the invention as a whole is that which is claimed, per Sec. 125(1) Patents Act 1977, and the inventive concept is the "new technical insight conveyed by the invention - the clever bit - as would be perceived by the skilled person". 35

\footnotetext{
23 Supra note 18.

24 [2018] EWCA Civ 2219, [2018] 10 WLUK 187. See previous summary in R. Trigg, "United Kingdom Patent Decisions 2018”. IIC 50:331-351 (2019). https://doi.org/10.1007/s40319-019-00796-y.

25 Supra note 19, para. [211].

26 Supra note 18.

27 [2018] EWCA Civ 1416, [2018] 6 WLUK 344. See previous summary in R. Trigg, "United Kingdom Patent Decisions 2018". IIC 50:331-351 (2019). https://doi.org/10.1007/s40319-019-00796-y.

28 Supra note 19, para. [213].

29 Supra note 19, para. [214].

30 Supra note 18.

31 [1993] RPC 513, [522].

32 Supra note 19, para. [219].

33 Supra note 24.

34 Supra note 19, para. [221].

35 Supra note 19, para. [222].
} 
After making this distinction, Hacon HHJ went on to apply the Actavis ${ }^{36}$ questions concerning the doctrine of equivalents to determine whether Estar's tubes were equivalent to Regen's claimed tubes.

Question 1 does the variant achieve substantially the same result in substantially the same way as the invention, i.e. the inventive concept revealed by the patent? Taking into consideration expert evidence, Hacon HHJ found that the inventive concept of claim 1 was exploited in substantially the same way to achieve substantially the same result when using the defendants' tubes.

Question 2 would it be obvious to the skilled person, reading the patent at the priority date, but knowing that the variant achieves substantially the same result as the invention, that it does so in substantially the same way as the invention? Hacon HHJ concluded "yes".

Question 3 would the skilled person, reading the Patent at the priority date, have concluded that the patentee nonetheless intended that strict compliance with the literal meaning of claim 1 was essential to the inventive concept? Hacon HHJ concluded "no". He said that the answer would only have been "yes" if there was a "sufficiently clear indication" to the skilled person that strict compliance with the numerical limit in the claim was intended. Hacon HHJ concluded that in this case there was no such indication. ${ }^{37}$

Hacon HHJ acknowledged that the prosecution history of a patent can be considered if it satisfies the requirements set by Lord Neuberger in Actavis. ${ }^{38}$ Hacon HHJ concluded that there was no issue of construction or scope which was unclear when considering the specification and claims of the patent and that it would not be contrary to public interest to ignore the letter adduced by the defendants from the patent's prosecution history.

In light of this, Hacon HHJ concluded that, had Regen's patent been valid, it would have been infringed according to the doctrine of equivalents. This decision has given us some clarity on how the doctrine of equivalents will be applied to claims with numerical limitations; potential defendants might still be held to infringe a patent even if they do not fall within a numerical limitation set out in the patent.

\section{Eli Lilly and Co v. Genentech Inc}

Next, we received two High Court judgments from Arnold J (as he then was), Eli Lilly and Co v. Genentech Inc ${ }^{39,40}$ concerning Genentech's patent for an anti-IL$17 \mathrm{~A} / \mathrm{F}$ antibody and its use in treating psoriasis and rheumatoid arthritis. Arnold J's (as he then was) first judgment concerned the validity of the patent ${ }^{41}$ and the second

\footnotetext{
36 Supra note 18.

37 Supra note 19, para. [252].

38 Supra note 18, para. [76] et seq.

39 [2019] EWHC 387 (Pat), [2019] 3 WLUK 15.

40 [2019] EWHC 388 (Pat), [2019] 3 WLUK 4.

41 Supra note 39.
} 
concerned the validity of a Supplementary Protection Certificate (SPC) sought by Genentech on the basis of the patent and Eli Lilly's marketing authorisation for its drug Taltz. ${ }^{42}$ The first judgment related to the plausibility of second medical use claims and the second concerned whether an SPC can be based on a third-party's (Eli Lilly's) market authorisation. Arnold J (as he then was) noted that this case was one of the most complex patent cases he has ever dealt with. ${ }^{43}$

Genentech's patent includes claims concerning the anti-IL-17A/F antibody itself and to the therapeutic uses of the antibody, framed as second medical use claims (in Swiss form (purpose-limited process claims) and in European Patent Convention 2000 (EPC 2000) form (purpose-limited product claims)). Eli Lilly markets an antiIL-17A antibody, which also binds to IL-17A/F, under the trade mark Taltz.

Eli Lilly launched proceedings challenging the validity of Genentech's patent on the grounds of lack of novelty, obviousness, and insufficiency. Eli Lilly also sought a declaration that if the SPC sought by Genentech was granted, it would not be valid. Eli Lilly argued that Taltz does not fall under the scope of Genentech's patent and therefore the SPC application would not comply with Art. 3(a) of the SPC Regulation. ${ }^{44}$ Eli Lilly further argued that the marketing authorisation for Taltz is a third-party authorisation and therefore Genentech's SPC application did not comply with Arts. 2, 3(b), and/or 3(d) of the SPC Regulation.

In the patent judgment, Arnold $\mathrm{J}$ (as he then was) concluded that the claims concerning the antibody itself were obvious as they related to rheumatoid arthritis. ${ }^{45}$ Eli Lilly had argued that the prior art had contained an enabling disclosure of the recombinant production of IL-17A/F and thus it would have been obvious to the skilled team to make antibodies to IL-17A/F and aim for the highest likelihood that the antibody could be put to therapeutic use.

Arnold $\mathrm{J}$ (as he then was) also found that the second medical use claims, only as they were directed to psoriasis, were insufficient for lack of plausibility. ${ }^{46} \mathrm{He}$ applied the law in relation to plausibility as set out in Warner-Lambert Co LLC $v$. Generics (UK) Ltd (t/a Mylan) ${ }^{47}$ and concluded that the relevant question to be asked was whether it was plausible that an IL-17A/F antibody would have a discernible therapeutic effect against psoriasis. Arnold J (as he then was) concluded that it was not plausible and that the claim with respect to psoriasis was "speculative". 48

In the SPC judgment, Arnold J (as he then was) concluded that the SPC application must fail in light of the invalidity finding. Despite this finding, Arnold $\mathbf{J}$ (as he then was) still submitted a reference to the CJEU concerning the use of thirdparty marketing authorisations in SPC applications. Specifically, Arnold J (as he

\footnotetext{
42 Supra note 40.

43 Supra note 39, para. [3].

44 Regulation 469/2009 concerning the supplementary protection certificate for medicinal products.

45 Supra note 39, see para. [618] for conclusion and paras. [397]-[521].

46 Supra note 39, see para [618] for conclusion and paras. [522]-[593].

47 [2018] UKSC 56, [2019] 3 All E.R. 95. See previous summary in R. Trigg, "United Kingdom Patent Decisions 2018”. IIC 50:331-351 (2019). https://doi.org/10.1007/s40319-019-00796-y.

48 Supra note 39, para. [577].
} 
then was) asked: "[d]oes the SPC Regulation preclude the grant of an SPC to the proprietor of a basic patent in respect of a product which is the subject of a marketing authorisation held by a third party without that party's consent?"

In discussing the need for making a reference in light of the patent finding, Arnold $\mathbf{J}$ (as he then was) concluded that he was convinced by arguments from Eli Lilly's counsel (among others) that if Genentech appealed the patent decision and was successful then the answer to the question would be of great importance. Arnold $\mathbf{J}$ (as he then was) highlighted the prospect of Brexit and noted that the English courts would lose the ability to refer questions to the CJEU when the UK leaves the European Union and it was better to make the reference now and withdraw it later if the circumstances rendered the reference unnecessary. ${ }^{49}$ We await the outcome of this reference to the CJEU.

\section{Actavis Group PTC EHF v. ICOS Corporation}

In March 2019, the Supreme Court delivered its first patent related decision of the year, Actavis Group PTC EHF v. ICOS Corporation, ${ }^{50}$ where it upheld the Court of Appeal's decision that ICOS's patent concerning a dosing regimen for the drug tadalafil was obvious.

The original first medical use patent for tadalafil (Daugan), used for treating erectile dysfunction, and its SPC expired. However, this dispute concerned ICOS's patent claiming a particular dosing regimen for tadalafil. Eli Lilly is the exclusive licensee of this patent and markets the drug under the trade mark Cialis. Actavis brought revocation proceedings against the ICOS patent in an attempt to clear the market for the launch of its own tadalafil generic. Actavis argued that the claims lacked novelty and inventive step in light of the original patent, Daugan.

The claim in dispute related to a dose regimen of up to $5 \mathrm{mg}$ of tadalafil per day. At first instance, ${ }^{51}$ Birss $\mathrm{J}$ found the patent valid; however, the Court of Appeal reversed the decision and found the patent invalid for lack of inventive step in view of Daugan. ${ }^{52}$ The Court of Appeal found that it would have been obvious for the skilled person to eventually try a dose of $5 \mathrm{mg}$ per day during the course of clinical trials (where other higher doses would be tested before eventually reaching the dose of $5 \mathrm{mg}$ ), which the Court found the skilled person would be highly motivated to do on the basis of the disclosure in Daugan.

ICOS and Eli Lilly appealed the Court of Appeal's decision, claiming that the Court of Appeal's approach to obviousness went beyond the requirements of Sec. 3 Patents Act 1977. They argued that Sec. 3 Patents Act 1977 should be a simple analysis of the question of whether the claimed invention would have been obvious to a skilled person, having regard to the state of the art, at the priority date and

\footnotetext{
49 Supra note 40, paras. [47] and [50].

50 [2019] UKSC 15, [2019] Bus. L.R. 1318; see IIC 50:1012-1013, https://doi.org/10.1007/s40319-01900865-2.

51 Actavis Group PTC EHF v. ICOS Corporation [2016] EWHC 1955 (Pat), [2016] 8 WLUK 146.

52 Actavis Group PTC EHF v. ICOS Corporation [2017] EWCA Civ 1671, [2017] 11 WLUK 8.
} 
should not involve the evaluation of the possible outcomes of potential clinical trials.

The Supreme Court, Lord Hodge delivering the judgment, did not agree with this reasoning, stating that this kind of analysis would require the court to disregard work the skilled person would carry out after the priority date to implement the teaching of the Daugan patent. ${ }^{53}$ Lord Hodge was clear to point that just because the notional skilled person has no inventive capacity, it does not mean that he/she has no skill to take the teaching of the prior art forward in an uninventive way. ${ }^{54}$

Lord Hodge spoke at length about the role of the inventive step requirement in patent law and emphasised that it must play a balancing role - ensuring that any patent monopoly granted corresponds to and is justified by the technical contribution to the art the invention has made. Lord Hodge emphasised that the test of inventive step is multifactorial and fact and patent specific. Lord Hodge listed nine factors relevant to this case. ${ }^{55}$ The Supreme Court ultimately upheld the Court of Appeal's finding that the patent lacked inventive step and dismissed ICOS's and Eli Lilly's appeal. Lord Hodge was quick to point out that products discovered by research involving standard pre-clinical and clinical tests could still be rewarded with a patent if the relevant statutory tests are met - this judgment has not affected that position. ${ }^{56}$

\section{E Mishan and Sons Inc (t/a Emson) v. Hozelock Ltd}

Next, we received a first instance judgment from Nugee $\mathbf{J}$ considering the issue of when a disclosure may be considered public, E Mishan and Sons Inc (t/a Emson) $v$. Hozelock Ltd. ${ }^{57}$ This case follows-up on the classic case dealing with when a disclosure made in public is considered public, Windsurfing International Inc $v$. Tabur Marine (Great Britain) Ltd. ${ }^{58}$

In Windsurfing ${ }^{59}$ it was held that the use of a sailing board by a young boy in an isolated coastal inlet did amount to a public disclosure because it had been potentially visible to anyone in the near vicinity; this is despite the fact that there was no evidence to suggest that anyone had observed the sailing board.

This case concerned expandable garden hoses which the inventor of the claimed invention had developed iteratively in his garden, which is publicly visible from the road. Nugee $\mathbf{J}$ considered whether this amounted to a public disclosure which rendered the patent obvious. Nugee $\mathbf{J}$ found that because the invention was developed iteratively, the invention would only be obvious in light of the disclosure if the separate disclosures of each developmental iteration were taken together as a

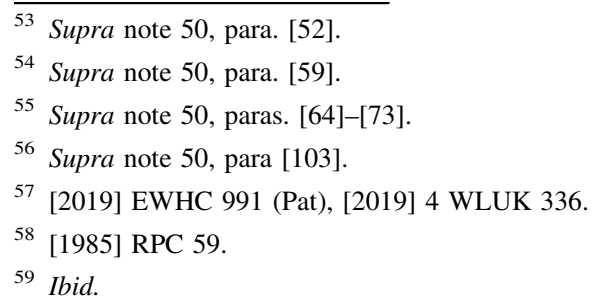


whole. Thus, the key question to be answered was whether the skilled person would have been motivated to watch the inventor with his prototypes on more than one occasion. Nugee $\mathbf{J}$ noted that this was not an easy question but ultimately concluded that the separate disclosures could not be combined together and, thus, there was no sufficient disclosure. ${ }^{60}$

Nugee $\mathbf{J}$ went on to consider obiter, in case he was wrong about whether the separate disclosures could be combined together, whether the inventor's activities amounted to public prior use. ${ }^{61}$ Nugee $\mathrm{J}$ summarised the present legal position that it is not necessary to prove that a disclosure made in public was seen but that it is the potential for it to be seen that is relevant. ${ }^{62}$ Nugee J, however, drew a distinction between the scenario where the public is given access to information, in whatever form, but no one takes up the opportunity to look at it versus the present scenario where no member of the public could have in fact got access to the information. Nugee $\mathbf{J}$ found, as a matter of fact, that if a member of the public had tried to observe the inventor in his garden, the inventor would have stopped what he was doing and packed up his prototypes thereby stopping any observation taking place. It is this distinction that allowed Nugee $\mathbf{J}$ to reach his conclusion that no public disclosure had been made by the inventor in his garden. ${ }^{63}$

Nugee $\mathbf{J}$ appears to have taken the law slightly further in this area by factoring in the intention of the potential discloser into the assessment of what amounts to a public disclosure. It is not clear whether this approach would be followed in cases where an inventor could have failed to notice an onlooking member of the public in order for them to be prompted to put their invention away. It seems that this case turned heavily on findings of fact, Nugee $J$ made a specific finding of fact that had anyone tried to observe the inventor in his garden then he would have packed away his prototypes. Of course, findings of such certainty may not always be possible given the nature of the location where the public disclosure is said to be made. Thus, it is not clear what, if any, impact this decision will have on future cases.

\section{Pfizer Ltd v. F Hoffmann-La Roche AG}

We next received a first instance judgment from Birss J, Pfizer Ltd v. F HoffmannLa Roche $A G{ }^{64}$ considering whether an Arrow declaration ${ }^{65}$ can be granted even where there is no possibility of any future UK patent rights being granted.

\footnotetext{
60 Supra note 57, paras. [131]-[133].

61 Supra note 57, para. [135] et seq.

62 Supra note 57, para. [141].

63 Supra note 57, paras. [148]-[149].

64 [2019] EWHC 1520 (Pat), [2019] 6 WLUK 324.

65 A declaration that a generic drug was known or obvious at the priority date of divisional patent application such that any future patent covering that product would necessarily be invalid. See Arrow Generics Ltd v. Merck \& Co Inc [2007] EWHC 1900 (Pat), [2008] Bus. L.R. 487. Such a declaration can be used as a Gillette defence, i.e. showing that a product was neither new nor obvious over the prior art at the priority date of the patent the product is alleged to infringe. See Gillette Safety Razor v. AngloAmerican Trading [1913] 30 RPC 465.
} 
This case concerned the drug bevacizumab, for which Roche has an SPC, which expires in June 2020, and that it markets for the treatment of cancer under the brand name Avastin. Pfizer has produced its own bevacizumab biosimilar which it intends to market upon the expiry of Roche's SPC. Pfizer applied for an Arrow declaration because it said that Roche has a "thicket of second-line patents and patent applications" which hinder Pfizer and cause it uncertainty. Pfizer argued that an Arrow declaration should be given because any second line patents granted would necessarily lack novelty and inventive step.

It was previously established in English law that an Arrow declaration should only be granted if it would serve a "useful purpose". ${ }^{66}$ However, the parties disagreed as to what constituted a useful purpose. At the time of the trial, Roche had no UK designated patents and it had removed the UK designation from all relevant pending EP patent applications. Thus, Roche argued that an Arrow declaration would not be useful as no future UK patent rights in this respect were possible. Pfizer argued for a more expansive view of what amounts to a useful purpose and argued that such a declaration would provide it with more commercial certainty and could be used in proceedings in Belgium, where Pfizer planned to supply the UK market from and where Roche still had designations in relevant pending patent applications.

Birss J concluded, by reference to Carr J's judgment in FujiFilm Kyowa Kirin Biologics Co Ltd v. AbbVie Biotechnology Ltd, ${ }^{67}$ that just because there is no UK right does not mean that an Arrow declaration may not serve a useful purpose. ${ }^{68}$ Birss $\mathbf{J}$ concluded that an Arrow declaration would have real commercial value to Pfizer. ${ }^{69}$ However, he concluded that the real reason Pfizer wanted the declaration was to use it in foreign courts, namely in Belgium. Birss $\mathbf{J}$ was not convinced that this was reason enough to grant an Arrow declaration and therefore denied Pfizer's application. $^{70}$

Thus, it is clear that the lack of UK patent rights will not necessarily prevent the possibility of an Arrow declaration being granted, provided that the party requesting the declaration can prove that there is a "useful purpose" for the declaration. Thus, it will not always be effective to de-designate the UK from pending patent applications in an attempt to avoid an Arrow declaration; however, in this case Roche's strategy to do just that did prove to be effective.

\section{Takeda UK Ltd v. F Hoffman-La Roche AG}

We later received another High Court decision from Birss J, Takeda UK Ltd $v$. $F$ Hoffman-La Roche $A G,^{71}$ dealing with Takeda's monoclonal antibody drug,

\footnotetext{
66 See Glaxo Group Ltd v. Vectura Ltd [2018] EWCA Civ 1496, para. [25].

67 [2017] EWHC 395 (Pat), [2017] 3 WLUK 104.

68 Supra note 64, para. [86].

69 Supra note 64, para. [115].

70 Supra note 64, para. [122].

71 [2019] EWHC 1911, [2019] Bus. L.R. 2681.
} 
Entyvio (a formulation of vedolizumab), approved for the treatment of ulcerative colitis and Crohn's disease, and Roche's patent concerning "glycosylated antibodies". This was a long and detailed decision covering issues of claim construction, infringement, novelty, obviousness/inventive step, and sufficiency.

This action started with Takeda bringing a claim for revocation of Roche's patent. Roche counterclaimed asserting that vedolizumab (and therefore Entyvio) infringes its patent.

Roche's patent related to a glycosylated human monoclonal antibody with at least $99 \%$ fucose within its sugar chain (when analysed by Liquid Chromatography/ Mass Spectrometry (LCMS) peptide map analysis). The figures of the patent showed that a high level of fucosylation led to a reduction in antibody dependent cellular cytotoxicity (ADCC).

Birss $\mathbf{J}$ first had to consider claim construction and what amounted to an "antibody" in the patent. The definition of "antibody" in the claim required the antibody to have a functionally active (FcR binding) Fc region, with glycosylation at Asn 297. Birss J construed antibody in accordance with this definition and said that the antibody receptor binding region needed to be structurally capable of binding an antibody receptor and mediating cell death. The high fucosylation was said to prevent normally functioning cell death activity of the receptor binding region.

Birss $\mathrm{J}$ then went on to consider infringement - did vedolizumab (and therefore Entyvio) fall within the scope of the claims? Evidence in the case showed that vedolizumab did have a functionally active Fc region but did not cause cell death (ADCC). Takeda asserted that this lack of cell death was a result of a mutation in the receptor binding region of the antibody (and not due to high fucosylation). Thus, Takeda argued that the receptor binding region in vedolizumab was not functional, with or without fucosylation of the antibody.

Conversely, Roche argued that vedolizumab did have a functionally active receptor binding region and that vedolizumab's ability to cause cell death was not entirely removed by the mutation. Thus, it said that vedolizumab's inability to cause cell death was as a result of fucosylation. After considering the arguments of both sides, Birss $\mathbf{J}$ concluded that vedolizumab did show a small amount of antibody receptor binding activity and therefore could be said to have a functionally active Fc region. Vedolizumab, therefore, fell within the scope of the patent. ${ }^{72}$

Birss $\mathbf{J}$ then turned to consider the novelty of the patent. Birss $\mathbf{J}$ concluded that the patent lacked novelty over a number of pieces of prior art. ${ }^{73}$ The prior art was said to disclose the idea of an antibody with somewhere between $99 \%$ and $100 \%$ fucose and that, combined with the common general knowledge, would have allowed the skilled person to make such an antibody without undue burden. ${ }^{74}$

Birss $\mathbf{J}$ then proceeded to consider obviousness/inventive step. Birss $\mathbf{J}$ was keen to answer whether the claim provided a technical contribution that had been

\footnotetext{
72 Ibid. See paras. [115]-[116] for Birss J's conclusion. For the wider discussion, see paras. [51]-[116].

73 Supra note 71, see complete discussion of novelty at paras. [117]-[195]. See specific discussion of each piece of prior art considered at paras. [136]-[195].

74 Supra note 71, para. [156].
} 
plausibly demonstrated across the breadth of the claim. Roche set out three contributions it claimed were made by the patent ${ }^{75}$ and Birss $\mathrm{J}$ said that there were five questions to ask in respect of each purported contribution: (1) is it disclosed in the patent; (2) is it plausible; (3) is it true; (4) is it a technical advance; and (5) does it support claims of the breadth they are ${ }^{76}$

Birss J ultimately concluded that the data in the patent did not support the breadth of the claim:

Figure 1 makes plausible the idea that the antibody tested reduces ADCC. It also makes plausible the idea that the antibody exhibits no ADCC at the concentration (presumably) tested. However it does not make plausible a wider proposition about the effect at higher concentrations since it simply does not address it. Rather than eliminating ADCC at any relevant concentration, for all the skilled person knows what has happened is simply that for the antibody tested, the concentration at which ADCC occurs has been increased above the level in the Figure. Nor am I convinced the proposition is true. Vedolizumab does not prove it since that antibody has a LAGA mutation. There is no other proof to which my attention has been drawn. ${ }^{77}$

Takeda's case of invalidity due to obviousness/lack of technical advance was made out. $^{78}$

Birss $\mathbf{J}$ finally went on to consider insufficiency. Takeda raised a number of points relating to insufficiency and Birss $\mathrm{J}$ reached strong conclusions regarding the ambiguity of the relevant claim. Birss $\mathbf{J}$ stated that it would not be clear to the skilled person whether or not a particular antibody fell within the claim as testing on different machines could lead to different answers. Birss J concluded: "The ambiguity is not of a kind which reveals a fuzzy boundary at the edge of the claim. The claim is truly ambiguous and invalid." 79

Thus, whilst Birss $\mathbf{J}$ held that vedolizumab was an antibody that fell within the claims of the patent, all of the relevant claims were invalid. The claims were said to lack novelty and a technical contribution, and were insufficient. Birss J ultimately concluded that the patent ought to be revoked. ${ }^{80}$

\section{Anan Kasei Co Ltd v. Neo Chemicals and Oxides Ltd}

We next received another Court of Appeal decision concerning insufficiency in the form of Anan Kasei Co Ltd v. Neo Chemicals and Oxides Ltd (formerly Molycorp Chemicals and Oxides Limited). ${ }^{81}$ This case considered both Kirin Amgen

\footnotetext{
75 Supra note 71, para. [206].

76 Supra note 71, para. [207].

77 Supra note 71, paras. [222]-[223].

78 Supra note 71, para. [225].

79 Supra note 71, para. [254].

${ }^{80}$ Supra note 71, para. [257].

81 [2019] EWCA Civ 1646, [2019] 10 WLUK 168.
} 
insufficiency ${ }^{82}$ and Biogen insufficiency. ${ }^{83}$ This case was appealed from the High Court where the patent at issue, concerning an improved version of the catalyst ceric oxide, had been upheld and Neo's arguments of obviousness and insufficiency failed. $^{84}$

The Court of Appeal, the main judgment delivered by Floyd LJ, first had to deal with construing the phrase "consisting essentially of". Claim 1 of the patent claimed, inter alia, "ceric oxide consisting essentially of a ceric oxide". Floyd LJ noted that this phrase, "consisting essentially of", sits between a distinction made in "patent jargon" between "consisting" and "comprising". "Consisting" is normally considered to mean that nothing else is present than what is specified, whereas, with "comprising" whatever is specified is taken to mean a minimum requirement and is agnostic as to whether anything else is also included. ${ }^{85}$

Floyd LJ concluded that "consisting essentially of" is a "hybrid" of these formulations. The parties had agreed that the skilled person would have regard to the practice of the EPO meaning that this phrase meant, apart from the mandatory ingredient, no other ingredients that materially affect the essential characteristic of the product are present. Floyd LJ therefore concluded, "[ $\mathrm{t}]$ he words would therefore be understood to provide a penumbra around the core of the claim, which is to pure ceric oxide having the required characteristics. How much of a penumbra is determined by the point at which the added ingredient starts to have a material effect on the essential characteristics of the product." 86

Thus, the real question of the appeal became whether the skilled person would be able to perform the invention in light of the above construal. Floyd LJ first dealt with the Kirin Amgen insufficiency arguments, namely that the claim was insufficient because it was conceptually uncertain. ${ }^{87}$ Neo argued that the skilled person would be uncertain whether a ceric oxide came within the scope of the claim and that they would be placed under an undue burden to determine for themselves whether any additional ingredients in the ceric oxide materially affected its characteristics. Floyd LJ rejected this argument concluding that this claim of undue burden was not made out in evidence. ${ }^{88}$ Floyd LJ, thus, rejected Neo's insufficiency due to uncertainty arguments.

Floyd LJ then moved on to consider the second insufficiency argument, Biogen insufficiency. ${ }^{89}$ The relevant claim here defined the ceric oxide by reference to its

\footnotetext{
82 See Kirin-Amgen Inc v. Hoechst Marion Roussel Limited [2004] UKHL 46, [2005] 1 All E.R. 667. This type of insufficiency deals with cases where a claim is rendered insufficient due to "uncertainty" (the phrase preferred by Floyd LJ) or "ambiguity" (the phrase preferred by Lewison LJ).

83 See Biogen Inc v. Medeva Plc [1996] UKHL 18, [1996] 10 WLUK 486 which set out the principle that the invention must be enabled across the entire scope of the claim, i.e. a patentee cannot claim for more than they have disclosed how to achieve.

${ }^{84}$ See Anan Kasei Co Ltd v. Molycorp Chemicals \& Oxides (Europe) Ltd [2018] EWHC 843 (Pat), [2018] 4 WLUK 371.

85 Supra note 81, paras. [13]-[14].

86 Supra note 81, paras. [13]-[14].

87 Supra note 81, para. [18] et seq.

88 Supra note 81, para. [30].

89 Supra note 81, para. [34] et seq.
} 
functional properties. Neo argued that this amounted a "wish list" and that the claim covered subject-matter that "required no invention" as taught by the patent. ${ }^{90}$ Floyd LJ also rejected this argument; it was not enough for Neo to make an assertion that there were embodiments covered by the patent that could not be made. It is clear that for this type of insufficiency to be made out there must be more than a mere assertion, Floyd LJ concluded: "They [Neo] had positively to establish that there were structures which were covered by the claim which could not be made with the benefit of that teaching. There is no reason for the court to assume that the claim covers structures which owe nothing to Rhodia's contribution to the art." 91 Floyd LJ therefore rejected Neo's Biogen insufficiency claims and upheld the High Court decision upholding the patent.

\section{Shanks v. Unilever Plc}

We then received the second patent related decision from the Supreme Court, Shanks $v$. Unilever Plc. ${ }^{92}$ This case concerned a long running battle between a former employee, Professor Shanks, and his former employer, Unilever. Professor Shanks had sought compensation from his former employer for an invention he devised during the course of his employment. Professor Shanks had lost his previous attempts to secure compensation at the UKIPO, the Patents Court, and the Court of Appeal; however, the Supreme Court upheld his appeal and awarded $£ 2$ million in compensation. The Supreme Court considered the circumstances in which such compensation may be awarded and how any such compensation is calculated.

Per Sec. 40 Patents Act 1977, an employee may be awarded compensation for a patented invention if the patent or the invention has provided an "outstanding benefit" to the employer. However, such outstanding benefit is assessed in the context of the size and nature of the employer's undertaking. ${ }^{93}$ It is this aspect of the test which was crucial to this case.

Here, the invention in question related to technology used in glucose testing for diabetics, which Professor Shanks had invented whilst employed by Unilever (by a subsidiary in the research arm of Unilever). There was no dispute that the rights in this invention belonged to Unilever as Professor Shanks had assigned his rights to Unilever. Unilever did not commercialise the resultant technology itself but licensed it out and eventually sold the relevant patents as part of the sale of its diagnostics business. It was calculated that Professor Shanks' invention had earned Unilever approximately $£ 24$ million. ${ }^{94}$

\footnotetext{
90 Supra note 81, para. [34].

91 Supra note 81, para. [59].

92 [2019] UKSC 45, [2019] 1 W.L.R. 5997; for the headnotes to this decision see IIC 51:107-108. https:// orcid.org/10.1007/s40319-019-00896-9.

93 See Sec. 40(1)(b) Patents Act 1977.

94 Supra note 92, para. [2] et seq. for summary of the facts.
} 
Professor Shanks' claim was originally heard by the Patents Comptroller in the $\mathrm{UKIPO}^{95}$ who found that, having regard to the size and nature of Unilever's business, the benefit provided by Professor Shanks' invention was not outstanding. On appeal to both the High Court ${ }^{96}$ and the Court of Appeal, ${ }^{97}$ both courts found that the Comptroller had not erred in principle in finding that the contribution by Professor Shanks' invention had not been outstanding. ${ }^{98}$ Professor Shanks argued that on the Comptroller's analysis, that outstanding benefit must be assessed by comparison to the employer's total profits, Unilever would always be "too big to pay". 99

The Supreme Court, Lord Kitchin delivering judgment, said that the starting point for determining whether an employee is entitled to compensation is identifying the employee's employer and this is taken to mean their actual employer. ${ }^{100}$ The test then requires that the benefit of the invention is identified; this was taken to mean the benefit of the patent after deducting any costs for securing the benefit. ${ }^{101}$ The assessment then turns to assessing whether that benefit has been outstanding (which is given the ordinary English meaning ${ }^{102}$ ), but this assessment, as set out in the Patents Act 1977, must be made in the context of having regard to the size and nature of the employer's undertaking. Lord Kitchin said this gave rise to two further questions: (1) what is the employer's undertaking for this purpose; and (2) what is the relevance of that undertaking's size and nature?

In this case, Lord Kitchin acknowledged that the first question was "difficult" given that Professor Shanks was employed by a smaller research arm of a larger group of companies, whereby the research produced by the research arm was exploited by the larger group of companies as a whole. Thus, the key question was whether the relevant undertaking was the research arm or the larger group. ${ }^{103}$

Lord Kitchin concluded that the correct approach is

to look at the commercial reality of the situation but to do so, in a case such as the present, from the perspective of the inventor's employer. Where, as here, a group company operates a research facility for the benefit of the whole group and the work results in patents which are assigned to other group members for their benefit, the focus of the inquiry into whether any one of those patents is of outstanding benefit to the company must be the extent of the benefit of that patent to the group and how that compares with the benefits derived by the group from other patents for inventions arising from the research carried out

\footnotetext{
95 BL O/259/13.

96 Shanks v. Unilever Plc [2014] EWHC 1647 (Pat), [2014] 5 WLUK 883.

97 Shanks v. Unilever Plc [2017] EWCA Civ 2, [2017] Bus. L.R. 883.

98 Supra note 92, para. [19] et seq for the history of the proceedings.

99 Supra note 92, para. [50].

100 Supra note 92, para. [31].

101 Supra note 92, para. [35].

102 Supra note 92, para. [39].

103 Supra note 92, para. [42].
} 
by that company. This gives practical and commercial effect to the language of section 41 and involves a comparison of like with like. ${ }^{104}$

Lord Kitchin then looked to understanding the relevance of the undertaking's size and nature. Lord Kitchin said that there is no single answer to this and concluded that many different aspects of the size and nature of the employer's business may be relevant. In some cases, the assessment of outstanding benefit may be conducted by simply looking at the size and profitability of the whole business but in other cases this would not be appropriate. Lord Kitchin was keen to warn against only considering overall profitability; indeed, noting:

Those profits and sales may have been generated by a range of different products which have nothing to do with the technology the subject of the patent; the parts of the business responsible for them may not have contributed to any commercial success of the patented invention; and they may be a very poor guide to whether the benefit the employer has derived from the patent is out of the ordinary. ${ }^{105}$

Lord Kitchin concluded that the Comptroller at the UK IPO had begun with the wrong starting point and therefore was wrong in principle for this reason. Lord Kitchin found that Professor Shanks had been employed by the research arm of Unilever and not the wider Unilever company and therefore it was the size and nature of this undertaking (the smaller research arm) that the Comptroller should have had regard to when considering "outstanding benefit". 106

Once at this new starting point, the Supreme Court concluded that the patents covering Professor Shanks' invention had been of outstanding benefit. Lord Kitchen noted:

... the rewards it enjoyed were substantial and significant, were generated at no significant risk, reflected a very high rate of return, and stood out in comparison with the benefit Unilever derived from other patents. What was more, they could not be attributed to the deployment or application of Unilever's wider business assets or infrastructure; nor were they found to be the consequence of any leverage Unilever could exert because of its size. ${ }^{107}$

In conclusion, the Supreme Court did not change the nature of the test for outstanding benefit set out in Sec. 40 Patents Act 1977; the test still requires that the overall profits and sales should be taken into consideration. However, the test requires that the scope of the appropriate undertaking be properly considered. Thus, if an employee is employed by a subsidiary of a large group of companies whose business activities, fields of business, or products are very different to the larger group, then this should be taken into consideration. Thus, whilst at first instance this appears to be quite an impactful decision, it is really likely only to affect large

\footnotetext{
104 Supra note 92, para. [48].

105 Supra note 92, para. [54].

106 Supra note 92, para. [79].

107 Supra note 92, para. [85].
} 
companies with a broad range of business areas and therefore its impact will likely be far less than might be initially thought.

\section{Teva v. Gilead}

Lastly, we received a judgment from the Court of Appeal just prior to the end of 2019, Teva UK Ltd v. Gilead Sciences Inc, ${ }^{108}$ concerning SPCs. This case was an appeal from the High Court of Arnold J's (as he then was) decision finding that Gilead's SPC protecting its combination HIV anti-retroviral drug, marketed under the brand name Truvada, was invalid. ${ }^{109}$ Truvada is a combination of tenofovir disoproxil and emtricitabine and Gilead claimed that this product was protected by a claim in one of its patents. Teva (and other generics companies) asserted that this specific patent did not protect the combination of drugs in Truvada and therefore the SPC was also invalid. ${ }^{110}$

This dispute has a long and complicated history which involved a referral to the CJEU from Arnold $\mathbf{J}$ (as he then was) asking for clarification on the meaning of Art. 3(a) SPC Regulation. ${ }^{111}$ This referral resulted in an answer from CJEU (Grand Chamber) where in it provided a two-stage test for determining whether a product is protected by a basic patent in force ${ }^{112}$ :

the answer to the question referred is that Article 3(a) of Regulation No $469 / 2009$ must be interpreted as meaning that a product composed of several active ingredients with a combined effect is "protected by a basic patent in force" within the meaning of that provision where, even if the combination of active ingredients of which that product is composed is not expressly mentioned in the claims of the basic patent, those claims relate necessarily and specifically to that combination. For that purpose, from the point of view of a person skilled in the art and on the basis of the prior art at the filing date or priority date of the basic patent:

- the combination of those active ingredients must necessarily, in the light of the description and drawings of that patent, fall under the invention covered by that patent, and

- each of those active ingredients must be specifically identifiable, in the light of all the information disclosed by that patent. ${ }^{113}$

\footnotetext{
108 [2019] EWCA Civ 2272, [2019] 12 WLUK 276.

109 See Teva UK Ltd v. Gilead Sciences Inc [2018] EWHC 2416 (Pat), [2018] 9 WLUK 185.

110 Article 3(a) SPC Regulation stipulates that an SPC can only be granted if the relevant product is protected by a basic patent in force.

111 See Teva UK Ltd v. Gilead Sciences Inc [2017] EWHC 13 (Pat), [2017] 1 WLUK 130. Arnold J asked "What are the criteria for deciding whether 'the product is protected by a basic patent in force' in Article 3(a) of the SPC Regulation?".

112 See Case C-121/17 Teva UK and Others v. Gilead Sciences Inc [2018].

113 Ibid, para. [57].
} 
Thus, in light of the CJEU's decision on how to assess whether a product is "protected by a basic patent in force", Arnold J (as he then was) was asked to provide his judgment on whether Truvada was protected be a basic patent in force. Arnold $\mathbf{J}$ (as he then was) applied the two-stage set out by the CJEU and concluded that Gilead's SPC was invalid.

As to the first stage, Arnold J (as he then was) said:

... from the point of view of a person skilled in the art and on the basis of the prior art at the priority date, the combination of active ingredients must necessarily, in the light of the description and drawings of the patent, fall under the invention covered by that patent. As explained above, this is not a simple extent of protection test. Rather, the combination must be one that the skilled person would understand, on the basis of the description and drawings and their common general knowledge, to embody the technical contribution made by the patent. ${ }^{114}$

Arnold J (as he then was) goes on to say that Gilead's patent does not say anything about combining tenofovir disoproxil and emtricitabine for treating HIV; it does not actually mention emtricitabine at all. The patent merely suggests that the claimed compounds may be combined with other therapeutic ingredients. Thus, Arnold J (as he then was) concluded that there is no basis in the patent for the skilled person to understand that the combination of tenofovir disoproxil and emtricitabine embodies the technical contribution of the patent. ${ }^{115}$ Gilead failed the first part of the twostage test.

Moving on the second-stage, Arnold $\mathbf{J}$ (as he then was) found that Gilead also failed this. Arnold $\mathbf{J}$ (as he then was) said of the second-stage:

from the point of view of a person skilled in the art and on the basis of the prior art at the priority date, each of the active ingredients must be specifically identifiable, in the light of all the information disclosed by the patent. There is no dispute that TD is specifically identifiable. In my view it is clear that emtricitabine is not specifically identifiable. ${ }^{116}$

Arnold $\mathbf{J}$ (as he then was) went on to say that there was no evidence that the use of emtricitabine for the treatment of HIV in humans was known, let alone that it was common general knowledge. ${ }^{117}$ Thus, Gilead also failed the second part of the twostage test.

Gilead appealed this first instance decision and the Court of Appeal, Floyd LJ giving judgment, issued its decision, shortly before the end of 2019, dismissing Gilead's appeal and upholding the first instance decision. Floyd LJ gave a full run through of the case law thus far on the meaning of Art. 3(a) SPC Regulation ${ }^{118}$ and noted that "the CJEU has struggled with getting across to national courts its

\footnotetext{
${ }^{114}$ Supra note 109, para. [37].

115 Supra note 109, para. [38].

116 Supra note 109, para. [39].

117 Ibid.

118 Supra note 108, paras. [18]-[24].
} 
understanding of what is meant by a product being protected by a basic patent for the purposes of Article 3(a) of the SPC Regulation."119

Floyd LJ considered both stages of the two-stage test laid out by the CJEU. Of the first stage, Floyd LJ said it is a test "which examines whether each component of the combination product is required by the claim". ${ }^{120} \mathrm{He}$ concluded that on this formulation of the first limb, Gilead did not meet the requirement. Floyd LJ noted that the addition of "other therapeutic ingredients" in the claim was expressly made optional $^{121}$ and that there was no basis for the skilled person to conclude that "the product [Truvada] is specified as required for the solution of the technical problem disclosed by the patent". 122

As a result of this analysis of the first-stage of the two-stage test, the Court of Appeal dismissed Gilead's appeal. Floyd LJ noted that it was not necessary for the Court to consider the second-stage of the two-stage test. He felt that a number of further questions were prompted in this second-stage and that he would "prefer to leave those issues to a case in which their resolution affected the result". ${ }^{123}$ Given that the second-stage of this two-stage test was not fully explored here as Gilead had already fallen at the first hurdle, we can expect that this will be dealt further in cases to come. It seems that we still do not have all of the answers to understanding what criteria are necessary for meeting Art. 3(a) SPC Regulation.

Open Access This article is licensed under a Creative Commons Attribution 4.0 International License, which permits use, sharing, adaptation, distribution and reproduction in any medium or format, as long as you give appropriate credit to the original author(s) and the source, provide a link to the Creative Commons licence, and indicate if changes were made. The images or other third party material in this article are included in the article's Creative Commons licence, unless indicated otherwise in a credit line to the material. If material is not included in the article's Creative Commons licence and your intended use is not permitted by statutory regulation or exceeds the permitted use, you will need to obtain permission directly from the copyright holder. To view a copy of this licence, visit http:// creativecommons.org/licenses/by/4.0/.

Publisher's Note Springer Nature remains neutral with regard to jurisdictional claims in published maps and institutional affiliations.

\footnotetext{
119 Supra note 108, para. [18].

120 Supra note 108, para. [76].

121 Supra note 108, paras. [78]-[80].

122 Supra note 108, para. [83].

123 Supra note 108, para. [84].
} 